change: on observe le démarquage des noyaux, accompagné de l'augmentation de la radioactivité du cytoplasme (Tableau).

Localisation des traces dans les cellules du méristème radiculaire de Vicia faba des plantes incubées avec l'adénine-14 $\mathrm{C}$ à $4^{\circ}$ et transférées à $18^{\circ}$

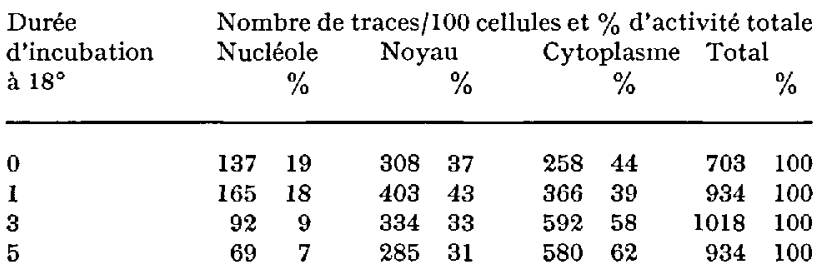

\section{Inhibition of Diapause in Pieris rapae L. by Brief Supplementary Photophases}

Unlike plants which show effects from interrupting the period of darkness by only a few seconds of light ${ }^{1}$, the light-phase reactions in insects and mites have been assumed to develop slowly ${ }^{2}$. Thus, when the effect of light on insects is studied, rearing in 'total darkness' is commonly reported without explaining how the test insects were fed, cleaned, or observed. This report purposes to show that Pieris rapae $\mathrm{L}$. resembles many other animals ${ }^{3}$ in responding to short photophases if the exposure to light occurs at a critical time.

Interruption of the dark period by 0.5 to $2 \mathrm{~h}$ of light was found by BÜNNING and JoERRENS ${ }^{4}$ to inhibit diapause most effectively at $14-16 \mathrm{~h}$ after the start of the 'main light period' in a $24 \mathrm{~h}$ cycle whether the main light period is 1,6 , or $12 \mathrm{~h}$. These authors suggest that with the start of the photophase, a physiological stage lasting about $12 \mathrm{~h}$ occurs in which light promotes diapause. This stage is followed by one in which light suppresses diapause. They assert that a critical period of darkness is not essential. In their tests a photophase of $0.5 \mathrm{~h}$ inhibited diapause less effectively in Pievis brassicae $\mathrm{L}$. than did $2 \mathrm{~h}$ of interrupting light. The shortest photophase otherwise found to affect arthropod diapause had been 1 to $3 h^{5-15}$. Most of these experiments were designed to test whether the light or the dark phase was the determinant and to detect possible additive effects of either phase. Reexamination of the published data tends to support the endodiurnal rhythm postulated by BüNNING and JokRRENS ${ }^{16}$.

The present tests on Pieris rapae $\mathrm{L}$. employed a $10 \mathrm{~h}$ main light period ( 1400 to 0000 daily) in a $24 \mathrm{~h}$ cycle. Supplementary light phases were added either to end $14 \mathrm{~h}$ after the start of the $10 \mathrm{~h}$ light period (0400) or to start $14 \mathrm{~h}$ before the end of the $10 \mathrm{~h}$ light period (1000). Effects of supplementary photophases of 150,90 , and $30 \mathrm{~min}$ on $P$. rapae have been reported ${ }^{17}$. In present tests identical techniques on 5,8 , and $17 \mathrm{~min}$ photophases were used.

When the interrupting photophase followed (off at 0400) the $10 \mathrm{~h}$ light period, the proportions of insects entering diapause at $20^{\circ} \mathrm{C}$ were $0 / 146$ for $90 \mathrm{~min}, 3 / 119$ for $30 \mathrm{~min}, 0 / 38$ for $17 \mathrm{~min}, 0 / 75$ for $8 \mathrm{~min}, 0 / 110$ for $5 \mathrm{~min}$, and $100 / 105$ for no interrupting light. When the interrupting photophase preceded (on at 1000) the $10 \mathrm{~h}$ light
En conclusion, l'incorporation cytoplasmique des précurseurs de $1^{\prime} \mathrm{ARN}$ et des protéines à $4^{\circ}$ est plus atteinte que l'incorporation nucléaire; il est bien possible que cette altération soit due à l'inhibition du transfert de l'ARN du noyau au cytoplasme.

Summary. The uptake of labelled RNA and protein precursors in Vicia faba root meristems into nuclei at $4^{\circ} \mathrm{C}$ is less depressed than in the cytoplasm. Reversion of the normal pattern of incorporation would seem to indicate an inhibition of the RNA transfer from nucleus to cytoplasm.

\section{J. Olszewska et B. Rodkiewicz}

Laboratoire d'Anatomie et de Cytologie végétales, Université de Lódź(Pologne), le 26 novembre 1962. period, the proportions of diapausing insects were $3 / 121$ for $150 \mathrm{~min}$ and $62 / 73$ for $5 \mathrm{~min}$.

These results agree with those of BüNNING and JOERRENS ${ }^{16}$ in that a supplementary photophase is more effective nearer the end of the main photophase. Even $5 \mathrm{~min}$ is not the limit of an effective inhibiting supplementary photophase. The timing cams used in these tests were accurate within $1 \mathrm{~min}$; more accurate timers will be needed in finding the shortest effective photophase.

Zusammenfassung. Es wurde festgestellt, dass u.a. auch Pieris rapae L. auf eine kurze nächtliche Beleuchtung antwortet, die einer wirkungslosen, täglich wiederkehrenden kurzen Photophase hinzugefügt wird. Die bei Pieris, gefundene wirksame 5minutige Beleuchtung ist die kürzeste Photophase, die bis jetzt für die Hemmung der Diapause bei Insekten bekannt geworden ist.

\section{R. J. BARKER}

Insect Physiology Laboratory, Entomology Research Division, Agricultural Research Service, U.S. Department of Agriculture, Beltsville (Maryland, U.S.A.),

October 29, 1962.

${ }^{1}$ M. W. PARker, S. B. Hendricks, H. A. Borthwick, and N. J. Scully, Bot. Gaz. 108, 1 (1946).

2 A. D. LeEs, Cold Spring Harbor Symp. Quart. Biol. 25, 261 (1960). 3 A. M. T́mme, Russian Rev. Biol, 49,223 (1960).

4 E. Bunning and G. Joerrens, Z. Naturforsch. $15 b, 205$ (1960).

5 P. L. Adkisson, Texas Agr. Exper. Sta., College Station, Texas, personal communication (1961).

B S. D. Beck, Biol. Bull. 122, 1 (1962).

'A. S. Danilyeysky and Y. I. Glinyanaya, Dokl. Akad. Nauk. SSSR 68,785 (1949).

${ }^{8}$ A. S. Danilyeysky and Y. I. Glinyanaya, Dokl. Akad. Nauk. SSSR $71,963(1950)$.

9 R. C. Drckson, Ann. Ent. Soc. Amer. 42, 511 (1949).

10 N. I. Goryshin, Ent. Oboz. 34, 9 (1955).

11 A. D. LeEs, Ann. Appl. Biol. 40, 449 (1953).

12 A. D. Lees, Ann. Appl. Biol, 40, 487 (1953).

13 A. D. Lees, Proc. First Internat. Photobiol, Congr. (Amsterdam 1954), p. 36.

14 H. J. MúlLer, Zool. Anz. Suppl, 18, 307 (1955).

15 A. F. Shull, Arch. Entwicklungsmech. 115, 825 (1929).

${ }^{10} \mathrm{E}$. Bunning and G. Joerrens, $Z$. Naturforsch. $17 b, 57$ (1962).

17 R. J. Barker, A. Mayer, and C. F. Cohen, Ann. Ent. Soc. Amer., in press. 